\title{
Organizational and Professional Competences Preparing Counsellors for Working with People Who Have Experienced Sexual Violence
}

\section{Kompetencje organizatorskie i zawodowe przygotowujace doradców do poradnictwa w zakresie przemocy seksualnej}

\begin{abstract}
This article addresses the issue of the competence of counsellors working with people experiencing sexual violence. The theoretical part of the article describes the basic concepts related to institutional (professional) counselling and describes a professional counsellor and his/her competences in a descriptive way. The subject of the research includes the competences of counsellors in the field of working with people who have experienced sexual violence. The purpose of the study was determining and describing their competences - both organizational and professional ones - from the perspective of the experience of individual listeners preparing for counselling work. The study uses a narrative method with content analysis. The research problem took the form of the following question: what are the competences of a counsellor in accompanying a sexually abused person from the perspective of the personal experience of future counsellors?
\end{abstract}

KEYWORDS

counselling, professional counsellor, sexual violence, organizational competences, professional competences

\section{SLOWA KLUCZOWE} poradnictwo, profesjonalny doradca, przemoc seksualna, kompetencje organizatorskie, kompetencje zawodowe

SPI Vol. 23, 2020/3

ISSN 2450-5358 e-ISSN 2450-5366 DOI: 10.12775/SPI.2020.3.006

Submitted: 25.04 .2020 Accepted: 23.05.2020

Miscellanea 
The research was conducted in 2019 among 23 postgraduate students preparing for counselling work. The results made it possible to select subcategories within the examined categories that show the specificity and value of the competences described by the respondents, and allowed us to emphasize the importance of the interdisciplinary knowledge and skills of counsellors. In addition, the conclusions of the study are valuable for pedagogical practice, especially in terms of enriching the offer of studies addressed to counsellors working with people who have experienced sexual violence.

\section{ABSTRAKT}

W artykule podjęto problematykę kompetencji doradców pracujacych z osobami doświadczającymi przemocy seksualnej. W części teoretycznej zostały opisane podstawowe pojęcia zwiqzane poradnictwem instytucjonalnym (profesjonalnym) oraz dokonano deskrypcyjnego ujęcia profesjonalnego doradcy i jego kompetencji. Przedmiotem badań uczyniono kompetencje doradców w zakresie pracy z osobami, które doświadczyły przemocy seksualnej, zaś celem określenie i opis ich profesjonalnych kompetencji (organizatorskich i zawodowych) w perspektywie doświadczeń indywidualnych słuchaczy przygotowujących się do pracy poradniczej. W badaniach posłużono się metoda narracyinq z wykorzystaniem analizy treści. Problem badawczy przyiał postać pytania: Jakie sq kompetencje doradcy w towarzyszeniu osobie wykorzystanej seksualnie w perspektywie doświadczeń osobistych przyszłych doradców? Badania przeprowadzono w 2019 roku wśród 23 słuchaczy studiów podyplomowych przygotowujących się do pracy poradniczej. Uzyskane wyniki badań pozwoliły na wyłonienie w ramach badanych kategorii subkategorii unaoczniajacych specyfikę i wartość opisywanych przez badanych kompetencji oraz wskazały na znaczenie interdyscyplinarności wiedzy i umiejętności doradców. Ponadto wnioski z badań sq wartościowe dla praktyki pedagogicznej, szczególnie w zakresie wzbogacania oferty studiów adresowanych do doradców pracujących z osobami doświadczającymi przemocy seksualnej.

\section{Introduction}

Suffering rooted in sexual violence is a severe experience in life. Nowadays, it is perceived as quite frequent yet unique, individual and intimate for the abused person, i.e. difficult to understand for others. 
Acts of sexual abuse destroy the innocence of children and youths, leading them to the limits of helplessness in suffering. The abused person suffers because of something he/she cannot influence, which is why the person feels helpless in a temporal perspective. He/she cannot change the past (Gadacz 2007: 202-203). This dramatic situation generates two possible solutions: one can do nothing, focusing on despair that closes one to happiness in everyday life; or one can try to find healing on one's own or with the support of other people. The latter solution requires courage, and it may include looking for advice given by competent counsellors.

The paradigm that became the basis for the research project is specifying counselling as a social action. Alicja Kargulowa assumes that solving the problems of the person who is looking for advice includes the optimization of the person's other actions or increasing his/her inner awareness. To facilitate the former, the counsellor should encourage the person to make decisions, confirm and reinforce them, or change the decisions into actions. The latter includes stimulating the person's reflectivity and increasing his/her freedom from fear and prejudice (Kargulowa 2011: 38). The essence of a counselling situation is the relation between the subject and object of the action. In order to meet this requirement, the counsellor should have the proper competences that prepare him/her for the social role that includes counselling.

In the pedagogy of work, organizational competences are perceived as basic, and they mean the pedagogue's ability to organize his/her work, to work on their own, and to establish one's objectives and priorities that have to be observed while performing their job (Wiatrowski 2005: 110; Korabiowska-Nowacka and Nowacki 1981). A broader perspective is presented by Janusz Figurski and Krzysztof Symela. They approach organizational competences in a way that is oriented at the working environment, both the material one (e.g. a separate room, the ability to make contact with the customer, and the privacy of the talks that are carried out) and the environment related to social conditions (planning the time for the work, constant contact with experts in various fields, the selection of proper methods) (Figurski and Symela 2004: 68). In counselling, the position of pedagogues is entirely related to the competences required in the working environment (Jańczak-Obst 2007: 249). 
Working with sexually abused people requires reliable professional competences from counsellors. Pedeutology shares this view. Stanisław Dylak explains that a pedagogue who wants to work in a constructive manner should constantly submit his/her knowledge and actions to reasonable criticism. Also, while maintaining high professional competences, he/she not only fulfils certain ways of counselling that are suggested to him/her, but he/she also creates some personal techniques of acting and developing knowledge (Dylak 1995: 37-39). The structure of pedagogical professional competences includes some good attitudes described with terms such as "aiming at," "being convinced of" or "being ready for" (Sajdak 2010: 131; Szempruch 2012: 187). This means focusing on professional actions, i.e. increasing professional competences (Męczkowska 2003: 694), life-long learning (Marynowicz-Hetka 2007: 86; Kwiatkowski 2007: 189-207) and the inclusion of educational and personal factors (Konopczyński 2007: 166).

This article aims at presenting two kinds of competences preparing counsellors for supporting people who have suffered sexual abuse. These are organizational and professional competences. In the presented perspective of sexual violence, nobody has dealt with the subject of such competences yet, so taking up research within this scope is treated as necessary. This field of work and the problems related to counselling are very sensitive, and any mistake by or negligence from the counsellor can result in the abused person's closure to the therapeutic process. Thus, in response to the needs of the unexplored area of knowledge, we have analyzed the professional competences of counsellors working with sexually abused people. We assume that promoting the research results shall improve the preparation of counsellors for working with sexually abused people and inspire scholars to explore the research field in question.

\section{Institutional (professional) counselling for underage people who have experienced sexual violence}

People who have experienced difficult situations have always searched for support from others, which is why counselling appeared. Counselling is useful to people on the path of their individual 
development, and it accompanies them at particular stages of their development (childhood, youth, adulthood, old age) (Kozdrowicz 1995: 319). It is especially important to focus on counselling related to the sexual abuse of underage people by adults. Monika Sajkowska claims that "childhood and adolescence is the period in which a person, as someone weaker than others, is an easy target for those who want to abuse him/her" (Sajkowska 2001: 193). Sexual violence is one of the worst traumas for a child. Such experience deprives him/ her of dignity and innocence and infringes the basic relationship of trust between the child and the adult. Scholars who analyze the phenomenon of sexual abuse are still discussing the scope of its definition. Taking into account the various meanings applied to this notion seems to be unjustified in this article. Małgorzata Henryka Kowalczyk has provided one of many definitions of sexual abuse, and this definition will be our point of reference. According to this author, "a child is sexually abused if a sexually mature adult, through conscious action or negligence of his/her social obligations, allows for making the child involved in any sexual activity aimed at the achievement of sexual satisfaction by the adult" (Kowalczyk 2014: 164). Maria Beisert emphasizes that all definitions of sexual abuse point to the area in which such abuse occurs. This area includes a person's sexuality, i.e. the field related to one's sex, related needs and the ways of satisfying those needs (Beisert 2004: 13).

Considerations concerning the sexual abuse of underage people lead to the establishment of proper counselling adequate to the situation. However, first of all, we have to try to define the very idea of counselling. The definition of Olga Czerniawska will be helpful in this respect. The author writes: "counselling can be specified as an action aimed at providing support through giving advice. Such action involves establishing a relationship between two or more people" (Czerniawska 1997: 7; Czerkawska 2018). From the point of view of the theoretical concept of David Finkelhor and Angela Brown, traumagenic mechanisms (such as traumatic sexualization, the sense of betrayal, powerlessness and stigmatization) are responses to experiences of sexual violence by underage people (Finkelhor and Brown 1985: 530-540). In the case of such people, the support of a counsellor seems to be necessary. First of all, it is because children and adolescents have to release their burden and experience relief in the 
presence of a counsellor (Bilska 1999: 69). Secondly, they need to overcome the trauma connected with their relationships with adults.

Caring for sexually abused children and adolescents requires the application of institutionalized (professional) support. According to Kargulowa, this kind of counselling should mainly be provided in an organized system of psychological-pedagogical counselling centres, and everything that takes place in such a centre falls within the scope of counselling (Kargulowa 2011: 50). The person who creates the situation in which counselling is provided is a professional counsellor (e.g. a pedagogue, psychologist, therapist). The person is prepared for such counselling through proper studies, social status and competences that determine a given kind of counselling (Pawłowska 1986: 22). Other features of a professional counsellor include intuition, reasonableness, compassion, mercy, and his/her own way of perceiving the world (Kargulowa 2011: 172).

The adoption of the above-mentioned descriptive assumption cannot narrow the area of institutional counselling, including within the scope of supporting children and adolescents who experience sexual violence, to the activities typical of a psychological-pedagogical counselling centre. The area of counselling is much broader and refers to the whole educational and upbringing system. Róża Pawłowska speaks about pedagogical counselling (Pawłowska 1986: 31) which includes a set of institutions that are to influence children and adolescents. These institutions include those that are both related and unrelated to schools, e.g. various care and upbringing units (day support centres, intervention centres, family and socialization institutions) in which the first counsellors in sexual violence may be teachers, pedagogues or psychologists. Also, taking into account the respondents of this research, we should also indicate other counsellors, i.e. people responsible for the religious education of children and youths, as well as diocesan representatives in charge of protecting children and adolescents. Such representatives are to receive information on priests sexually abusing underage people, and they are to provide psychological, legal and spiritual support to the abused children and teenagers (cf. Centrum Ochrony Dziecka n.d.). 


\section{Professional counsellor - descriptive approach to his/her}

\section{competences}

A counsellor involved in institutional support for underage people who were sexually abused has to be professional, contrary to other people who may deal with everyday counselling, such as parents, neighbours, fortune-tellers or friends (Siarkiewicz 2010: 26-28) or to people who give advice in the media (Zielińska-Pękał 2009: 285-307). A professional counsellor is someone whose job is to give advice to people, and Bożena Wojtasik and Alicja Kargulowa describe a counsellor in the categories of profession, passion and calling (Wojtasik and Kargulowa 2003). Before we specify which competences prepare a counsellor for working within the subject in question, first we have to define the very notion of competence, and then we will try to identify some of its kinds.

Competence is one of the important pedagogical notions to which it is hard to give an unequivocal meaning. That is why, in the books on this subject, the notion is defined in a more or less detailed manner. Władysław Kopaliński believes that competence is "the property and scope of qualifications to perform a particular task. To be competent is to be authorized to work on one's own" (Kopaliński 1989: 269). In turn, Czesław Kupisiewicz and Małgorzata Kupisiewicz emphasize that competence is the ability to fulfil oneself, as well as the skills and qualifications to perform tasks in a specific field, including professional work (Kupisiewicz and Kupisiewicz 2009: 82). While preparing to work with sexually abused people (children and adults), a counsellor is not only aware of his/her competences, but he/she also aims at being a reliable expert through gaining specialist knowledge and professional experience. Also, for pedagogues, it is important to approach competence from the perspective of Maria Dudzikowa: competence is a kind of a cognitive structure comprised of particular skills, enriched with knowledge and experience, built on the conviction that - with the use of those skills - one can and should, in a given situation, initiate and fulfil tasks related to a particular area according to adopted standards (Dudzikowa 1994: 141).

In the detailed identification of selected competences we will take into account literature related to the pedagogy of work and pedeutology. The adoption of several representative types of teacher 
competences in presenting the research results in this article should only be treated as an initial reflection, as they have not been described in detail. A counsellor working with people who have experienced sexual violence could possibly use these results. Robert Kwaśnica, for example, lists two groups of competences: a) practical-moral ones (interpretative, moral, communicative) and b) technical ones (postulative, methodical, fulfilment) (Kwaśnica 1995: 18-22). Stanisław Dylak mentions the following competences: a) interpretative ones (preparation for critical reflection), b) self-creative ones (self-knowledge, awareness of being in a relationship with other subjects, research attitude), and c) fulfilment ones (a broad range of skills which make it possible to fulfil educational tasks) (Dylak 1995: 38-41). Jolanta Szempruch, in turn, believes that a teacher should be characterized by the following competences: personal, interpretative-communicative, cooperative, creative-critical, innovative, pragmatic, and IT-media ones (Szempruch 2013: 101-113; Łukasik 2010). In the scope of working with people who have experienced sexual violence, the above lists of competences should not be treated as hard and clearly defined groups, but as "fluid, loose and negotiable skills and abilities" (Siarkiewicz, Trębińska-Szumigraj and Zielińska-Pękał 2012: 106). A counsellor should be aware of the fact that the competences they acquired during their professional education may be verified by the person who asks for advice in the counselling situation.

\section{Methodology of the author's own research}

In the academic year 2019/2020, the author of this article conducted classes at the Centrum Ochrony Dziecka (Child Protection Centre) at the Jesuit University Ignatianum as part of the "Selected Issues in Counselling" course. The classes inspired the author to carry out this research on the competences of counsellors working with sexually abused people. The respondents were 3rd-semester or postgraduate students on the "Prevention of sexual violence among children and youth" module. The objective of the studies is to gain knowledge, skills and competences related to applying good support practices (pedagogical, psychological and therapeutic) among people who have experienced sexual violence, with particular emphasis on children and adolescents. Because of the fact that counselling may 
also include adults who were sexually abused in their childhood or adolescence and, after many years, decided to overcome the trauma, the students of this specialization are also prepared to work with these recipients of counselling activities.

The competences of counsellors related to working with sexually abused people are the subject of the research. The objective of the research is to determine important competences of the counsellors working with people who have experienced sexual violence and describe them based on the examples of particular individuals. Moreover, the author aims at using the research results to enrich/complete the current educational offer for people who are preparing to work as professional counsellors.

The research problem took the form of the question: what are the competences of a counsellor who accompanies a sexually abused person from the perspective of the personal experiences of future counsellors? The research was carried out from October to December 2019. The selection of the research group was, on purpose, not probabilistic. Twenty-three students took part in the research: 12 men (monks or priests) and 11 women (4 nuns from various orders and 7 lay women). The research participants work as pedagogues, supervisors in education and care institutions, psychologists, diocesan representatives in charge of children and youth protection, a judge in the ecclesiastical court, as well as priests who catechize children in parishes. They live in different parts of Poland and are aged 30-50. It is worth emphasizing that most of the respondents are experienced in working with sexually abused people and that they have already conducted many counselling sessions with them. For empirical purposes, each respondent was anonymised and given a number, which, when presenting the respondents' replies, takes the form of a code, e.g. C10, where C stands for Counsellor, and 10 - the respondent's reference number.

The research falls within the scope of the paradigm of interpretative research that seeks to understand the meanings given by the respondents to various events and situations in life (Rubacha 2017: 139-143). The research was carried out in the form of written narratives (an essay), which made it possible for the students to express their opinion freely and to refer to their own experiences. The research was of an explorative nature. The categories of factors 
specified in the empirical part were later revealed during the analysis of the narrative content.

The respondents were to write an essay entitled Competences of a counsellor working with people who have experienced sexual violence. In the research, with the use of narratives, the author used the technique of essay content analysis in order to specify and describe particular categories and subcategories. Because of the guidelines related to the preparation of scientific articles in the presented publication, the analyses were limited to the following two categories: organizational and professional. Further analytical content will be elaborated in two forthcoming scientific articles.

\section{Competences that prepare a counsellor for working with sexually abused people - the results of the author's own research}

Before giving voice to the respondents who tried to specify and describe the competences of a counsellor, we will refer to a phenomenological reflection. This is an attempt to present an adequate formula to express the essence of the relationship between a person who has experienced sexual violence and a counsellor showing the person a horizon of hope because of the fact that human life is always open towards the future. Krystyna Ablewicz says: "in the experience of suffering, a person (...) has to be somehow present as a subject, and he/ she has to bear the burden of this 'trip.'The painfulness of a person's life is his/her irrevocable property. He/she can tell another person about it, but he/she cannot transmit or hand it over to someone else" (Ablewicz 1996: 56). Tadeusz Gadacz is of a similar opinion, claiming that "suffering can be described, but only described, to someone else. The suffering person must discover the meaning of this description on his/her own" (Gadacz 2007: 226). However, Józef Tischner goes a step further to give the suffering person the hope that there is another person (counsellor) who can receive the story about the helplessness of suffering. Tischner wrote: "to understand a person is to share his/her anxiety of the 'restless heart.' It sometimes even means to see him/her as someone better than they see themselves" (Tischner 1991: 8). The above reflection justifies the fact that, in this 
kind of counselling, which is demanding and difficult because of the issue of sexual violence, special competences are required of a counsellor. This is also mentioned in the utterances of the respondents. One of them writes: "The awareness of the complexity of the problem concerning the sexual abuse of children is insufficient in Poland. In a person's story and way of living it is difficult to identify the elements that are constantly present and that, in fact, result from being sexually harassed in childhood" (C5). Another person, while specifying the features of a counsellor, claims that professionalism is the leading competence, but we cannot ignore other skills that make the person suitable for working with sexually abused people: "It seems that the level of being professional is as important as what the counsellor/therapist is like - what the level of his/her maturity, mental health and life experience is" (C20).

In this text, I will present two categories of competences that prepare counsellors. These categories were revealed during the analysis of the written works received from the respondents. These categories are organizational and professional competences. Each of the categories is divided into various subcategories.

\section{Organizational competences}

We need to assume that organizational competences are the basic group of skills that a counsellor should have. These skills do not include the features of a leader, director or coordinator, but the ability to take into account the situation of the person who is seeking advice. This totally changes the perspective of counselling which, in phenomenological thought, is to become an event. According to Józefa Chmielewska, it requires going beyond oneself to build a dialogue between me and you, where you determine the essence of the meeting (Chmielewska 1995: 103). This is particularly important due to the sensitive nature of the experienced trauma and difficulties related to sharing it with the counsellor. The following organizational competences are mentioned in the respondents' utterances: time availability and working in a professional interdisciplinary team.

Time availability refers to the ability to organize a meeting that is not very strictly limited by time. According to one of the respondents, "Based on my experience, I do not establish exact hours and minutes. I am just available on a given day, and I give the person the freedom to 
choose the time" (C1). Another student writes the same: "In counselling it is crucial to have enough time not to disrupt the talk or the victim's utterance, as the person needs to express what happened to him/her" (C21). The people who seek advice also emphasize the advantages of time availability: "In everyday work, I often come across the question: how much time do you have for me? I always say: as much as you need. This answer is often shocking for the person, and practice shows that talking usually takes less than two hours. People tell me about their problems in a slow and uninterrupted manner, and I listen to them. Then, after a brief analysis, we try to specify the first step to make" (C1). According to Marcin Szumigraj, in a counselling situation, time is also needed when "the counsellor and the person seeking advice work together to formulate the proper problem" (Szumigraj 2009: 180). That is why one of the respondents emphasizes the ability to listen to the child's narrative: "The ability to listen to the child for as long as necessary, to listen to his/her needs, fears, and inner conflict, becomes the key to building the common world in the therapy of a child with the counsellor" (C10). On the other hand, the same respondent indicates negative consequences resulting from the lack of time availability of the counsellor, which is reflected in his/her undesired personality traits: "The lack of patience is reflected in perceptible irritation, ignoring the person or disrupting his/her utterances. None of these elements is desired when working with the person seeking advice. An impatient counsellor will try to deal with each problem quickly, but not necessarily well' (C10).

People who deal with the issue of sexual abuse should realize that solving the problems of children, youths and adults in counselling may, in a given situation, be too difficult for the counsellor. That is why the respondents rightly indicate that working in a professional interdisciplinary team is an important organizational competence. One of the respondents says: "Sexual violence results in many consequences in the victim's functioning. A complex approach of many different specialists is necessary if we want to help such a person" (C4). We can find a similar opinion in a text by another student: "Abusing a child leaves a permanent trace in his/her psyche. Solving all the problems related to this trauma may seem impossible at a given moment. Thus, we should use the knowledge and experience of other people who work with abused people" (C12). The author of this utterance emphasizes two more issues. First, she specifies the problem of sexually abused children that often 
takes the form of somatic symptoms, which is why medical support becomes necessary: "Traumatic experiences, especially those about which children have never talked, often result in somatic illnesses. Working with a good doctor may help specify the problem and implement adequate help" (C4). Second, "using the support of experienced experts in various fields increases our chance to diagnose the child properly and provide him/her with the proper therapy" (C4).

\section{Professional competences}

Professional competences are not permanent features. They change along with the person's experience, life-long education and development. They make it possible to fulfil professional tasks at the required level. Working as a counsellor who gives advice to sexually abused people must also take into account professional competences. In the respondents' utterances, the following features are mentioned: professionalism, leadership and awareness of one's emotions.

Professionalism as a competence that prepares people for counselling was indicated by a few respondents. This means that postgraduate students who, in many cases, are already working with people find it important. This is how they write about this: "I come to the conclusion that I have to be very well prepared if I want to be a good counsellor" (C1); "It is very difficult to help people who have experienced such a trauma, so it is very important to take into account the most important principles related to such counselling" (C4); "If a child or an adolescent seeks advice from a counsellor, the latter has to be professional and competent" (C8); "The specialist who, in a complex and professional manner, will be able to talk to the child and accompany him/her during the therapy has to be full of LOVE and WISDOM that should lead his/her way of helping the hurt and helpless little person" (C9); and "If we want to be counsellors, we have to be very well prepared to perform this kind of work and service" (C16).

One of the attributes of professionalism is having specialist knowledge related to the profession in question. Here are some of the respondents' utterances on this: "Thus, in a counselling relationship, helshe should have proper knowledge on the issues related to his/her area of action" (C3), and "The counsellor must constantly develop his/her 
knowledge, gain new skills and extend his/her horizons. Only a wisely shaped adult can properly (in a clever way) accompany and support a child" (C9).

Also, the students emphasize certain forms of shaping one's own professionalism. One of the respondents believes that this is carried out through "private study" (C1); another believes that it is based on "reading books, various forms of education, and an openness to using the experience of other people" (C3). One of the students emphasizes the meaning of using various methods in counselling: "A counsellor should be open to different methods of work. Using various forms of education makes it possible for him/her to climb higher and see the problem better. This skill makes the counsellor open to changes and brave enough to leave behind what is old and to apply something new" (C22). According to Bogusława Dorota Gołębniak, this approach is what makes a professional different to someone who just knows a given profession. Professionalism makes it possible for a person to resign from one valid pattern of work in order to modify and construct actions in practice (Gołębniak 2009: 43).

Also, the competence of leadership specifies the counsellor's professional profile, but it is not an ideal to be worked out or a model to be reproduced. Rather, the ability to lead the person seeking help is the counsellor's social and professional role, or even a kind of his/ her identity that should already be shaped before the beginning of counselling. In her utterance, one of the respondents refers to the person of a counsellor-guide and describes him/her in a metaphorical manner: "A guide should have eyes all around his/her head, i.e. he/she should look ahead and, at the same time, carefully watch the person helshe is leading. The guide is to adjust the tempo and degree of difficulty to the customer. Leadership is safe guidance in a situation in which the solitary way is impossible or very dangerous" (C3).

Another dimension of leadership is a particular sensitivity to the person who is telling a difficult story of their own suffering. Also, the counsellor needs humility because of the trust that the victim gives to the therapist. "On the one hand, I have to gently and carefully accept the person who came to me, and, on the other hand, I have to reply (although I am very moved by what I heard) to what has been brought to me and given to me only" (C16). Elżbieta Siarkiewicz perceives this kind of sensitivity of a counsellor as sacrum: "I do this because this meeting is 
important to me. This meeting is not an everyday issue, yet it grows out of everyday life as an event" (Siarkiewicz 2010: 114).

Assuming that emotions are a part of people's professional life, we cannot ignore them when working with people who have experienced sexual violence. The respondents indicate that the awareness of one's own emotions is an important competence of a counsellor. According to Joanna Madalińska-Michalak and Renata Góralska, the awareness and proper shaping of emotional competence may "result in the counsellor's strength and ability to cope with difficult situations, which may facilitate helping others, controlling the situation, persevering in the fulfilment of tasks, overcoming disappointment and taking up various challenges" (Madalińska-Michalak and Góralska 2012: 12; Kwiatkowski and Walczak 2017). Here is how the students speak about the awareness of their own emotions in counselling: "The person responsible for leading another person should, first of all, listen to his/her own emotions" (D21); "In the face of the crime that includes sexual abuse, along with obtaining more and more detailed data on the very act and its circumstances, the counsellor experiences various emotions" (C13); "When I accompany other people, I see how important it is for me to be aware of my own emotions" (C14); and "A counsellor who helps a sexually abused child must be aware of his/her own experiences and related emotions. Such emotions are natural; they are a normal reaction of each person" (C18).

The awareness of one's emotions leads the counsellor to think about the kinds of emotions that may accompany helping people who have experienced sexual violence. One of the respondents separates the emotions related to the victim (good ones) and to the offender (negative ones): "The child evokes emotions such as compassion, care, admiration, liking, i.e. good feelings that attract the counsellor to the child and make him/her want to help the child. Other emotions are related to the wrongdoer and to the circumstances of violence: anger, hatred, disgust, dislike, and other feelings that make us repulsed by the offender's actions" (C13). Another respondent, in turn, perceives both the good and bad emotions in a holistic manner: "When a counsellor listens to the victim's story and is aware of the fact that this happened to an innocent child, who was deeply and brutally hurt (even if the child is not fully aware of this), the counsellor experiences a range of different emotions: from feeling sorry for the victim, through sadness, to anger directed at the offender" (C18). 
The very fact of being aware of one's feelings may bring mutual benefits in counselling. First, the counsellor may evaluate his own work in a positive manner, and second, the child seeking advice may receive better support. "The emotions experienced by the counsellor, if they are conscious and properly interpreted, are usually a good guide in the relationship with the supported person: they make it easier to build the relationship, to adopt the victim's perspective, and to choose efficient therapeutic interventions at the proper moments" (C13). Here is another quotation: "A counsellor must be able to name one's own emotional states and care about one's own sensitivity and feelings. Then, he/she will be able to help people in a more efficient manner. It is important to know a lot, but if we interiorize all the information, listening and empathy bring relief to the people whom we help. This is a good effect" (C14).

Knowing and understanding one's own emotions is the basis for directing them within the whole process of counselling. It is important for the counsellor to avoid basic mistakes that include the lack of control over one's own emotions. Such control also determines the counsellor's professionalism. The respondents also mention these mistakes in their utterances. One of them claims that "one's feelings related to sexual abuse should be separated from what the victim experiences" (C13). Another respondent suggests a way of coping with emotions, which is to protect the counsellor against bad consequences of such feelings: "the counsellor should try to cope with the emotions so that they do not lead him/her to wrong decisions that break the professional rules. For example, a counsellor who works with drug addicts cannot try drugs to, for a moment, feel what his customers feel. A priest who supports a sexually abused adolescent does not have to have a similar story in his life" (C21).

Another respondent (C18) presented a thorough conclusion in the area of the analyzed category. In his utterance, he referred to three fundamental mistakes, awareness of which is necessary for a person who wants to become a counsellor: ignoring emotions, suppressing emotions and being unaware of one's emotions. 1) "A counsellor ignores his/her own emotions and pretends that they do not exist because he/she is a professional. In such a case there is a risk that the feelings shall explode anyway, in the least expected moment"; 2) "A counsellor suppresses his/her emotional responses, which also involves the risk of releasing them at an unexpected time. Even if the counsellor is able to suppress negative emotions with the power of his/her will, he/she must be aware of the fact 
that he/she shall bear the consequences of such behaviour as the tensions that appear this way may be revealed in another manner (e.g. in the relationships with his/her family members, with friends, or even in a somatic manner)"; and 3) "If a counsellor is not aware of his/her emotions, he/she may not control them. Helshe may even think that sharing them with the victim is right. Obviously, this way, the counsellor may hurt the victim even more: empathy is good, but we must not judge the offender on the basis of our own anger. Nor should we despair together with the victim, perceiving this as the proper form of showing our sympathy."

\section{Conclusions}

The narratives of postgraduate students who are preparing to work as counsellors with sexually abused people (children, youths and adults) specified two basic categories of competences within this scope: organizational and professional ones.

With organizational competences, the respondents paid great attention to the counsellor's time availability, giving it crucial significance in counselling. This seems to be obvious, as most people believe that a professional counsellor should be available to his/her patients. However, in practice, this is often not the case. And if the counsellor limits their time while talking to the person seeking help, the latter is stressed, which exerts a negative influence on the entire therapeutic process. Also, working in a professional interdisciplinary team, emphasized in the respondents' utterances, is an inseparable element of working with people who have experienced sexual violence. The indication of this organizational competence confirms the students' maturity, i.a. due to the fact that some of them, in their current work, use the knowledge and support of other experts.

The students' narratives also refer to the professional competences necessary for preparing to work with sexually abused people. The counsellor's professionalism, their ability to lead people and their awareness of their own emotions are the basic three pillars of counselling which intermingle with one another. Moreover, the respondents believe that responsibility, consciousness and reflectiveness are features of a counsellor's professionalism. Leading and accompanying another person in the helplessness of his/her suffering requires perfect preparation by a counsellor, which is reflected in the 
competences mentioned by the respondents. They are fully aware of this, and this is one of the reasons why they decided to take up postgraduate studies. In a similar manner, learning to be aware of one's emotions, which are to be guides when working with sexually abused people, would not be possible without the professional skills related to proper knowledge and communication abilities.

These research results may be the basis for enriching the existing educational offer concerning the professional preparation of counsellors or for modifying the existing courses carried out within postgraduate studies preparing professional counsellors.

\section{Bibliography}

Ablewicz K. (1996). "Cierpienie warunkiem wzrostu? Rozważania nad sensem bolesności życia w wymiarze pedagogicznym," Zeszyty Naukowe Uniwersytetu Jagiellońskiego. Prace Pedagogiczne, no. 25, pp. 51-65.

Beisert M. (2004). Kazirodztwo. Rodzice w roli sprawców, Warszawa: Wydawnictwo Naukowe Scholar.

Bilska E. (1999). "Pierwsza pomoc," in I. Pospiszyl (ed.), Razem przeciw przemocy, Warszawa: Wydawnictwo Akademickie "Żak", pp 69-95.

Centrum Ochrony Dziecka (n.d.). "Delegaci diecezjalni," https://cod.ignatianum.edu.pl/pomoc/delegaci-diecezjalni [access: 22.01.2020].

Chmielewska J. (1995). "Doświadczenie człowieka jako źródło refleksji etycznej," in H. Kwiatkowska, T. Lewowicki (eds.), Z zagadnień pedeutologii i ksztatcenia nauczycieli, Warszawa: Wydawnictwo Instytutu Technologii Eksploatacji, pp. 101-109.

Czerkawska A. (2018). "Ku dialogicznej więzi w poradnictwie humanistycznie zorientowanym," Studia Poradoznawcze, vol. 7, pp. 129-146.

Czerniawska O. (1997). Poradnictwo jako wzmocnienie środowiska wychowawczego, Warszawa: Instytut Wydawniczy CRZZ.

Dudzikowa M. (1994). "Kompetencje autokreacyjne - czy i jak są możliwe do nabycia w toku studiów pedagogicznych," in M. Dudzikowa, A.A. Kotusiewicz (eds.), Z pogranicza idei i praktyki edukacji nauczycielskiej, Białystok: Wydawnictwo Uniwersytetu Warszawskiego. Filia w Białymstoku, pp. 127-152.

Dylak S. (1995). Wizualizacja w ksztatceniu nauczycieli, Poznań: Wydawnictwo Naukowe Uniwersytetu im. Adama Mickiewicza.

Figurski J., Symela K. (2004). "Doradca zawodowy - wymagania kwalifikacyjne,” in H. Bednarczyk, J. Figurski, M. Żurek (eds.), Pedagogika pracy. Doradztwo zawodowe, Warszawa-Radom: Wyższa Szkoła Pedagogiczna; Instytut Technologii Eksploatacji, pp. 65-72. 
Finkelhor D., Brown A. (1985). "The Traumatic Impact of Child Sexual Abuse: A Conceptualization," American Journal of Orthopsychiatry, vol. 55, no. 4, pp. 530-540.

Gadacz T. (2007). O umiejętności życia, Kraków: Wydawnictwo Znak.

Gołębniak B.D. (2009). "Aplikacje konstruktywizmu do poradoznawstwa. Inspiracje pedentologiczne," in A. Kargulowa (ed.), Poradoznawstwo-kontynuacja dyskursu, Warszawa: Wydawnictwo Naukowe PWN, pp. 36-61.

Jańczak-Obst E. (2007). "Kompetencje osobiste doradcy," in V. Drabik-Podgórna (ed.), Poradnictwo. Między etykq a technikq, Kraków: Oficyna Wydawnicza "Impuls", pp. 247-261.

Kargulowa A. (2011). O teorii i praktyce poradnictwa. Odmiany poradoznawczego dyskursu, Warszawa: Wydawnictwo Naukowe PWN.

Konopczyński M. (2007). Metody twórczej resocjalizacji. Teoria i praktyka wychowawcza, Warszawa: Wydawnictwo Naukowe PWN.

Kopaliński W. (1989). Stownik wyrazów obcych i zwrotów obcojezzycznych, Warszawa: Wydawnictwo Wiedza Powszechna.

Korabiowska-Nowacka H., Nowacki T. (1981). Pedagogika pracy, Wrocław: Zakład Narodowy im. Ossolińskich

Kowalczyk M.H. (2014). Przestępcy seksualni. Zabójcy, grwatciciele, pedofile i ich resocjalizacja, Toruń: Wydawnictwo Naukowe Uniwersytetu Mikołaja Kopernika.

Kozdrowicz E. (1995). "Poradnictwo w teorii i praktyce," in T. Pilch, I. Lepalczyk (eds.), Pedagogika spoteczna. Cztowiek w zmieniającym się świecie, Warszawa: Wydawnictwo Akademickie “Żak”, pp. 319-339.

Kupisiewicz C., Kupisiewicz M. (2009). Stownik pedagogiczny, Warszawa: Wydawnictwo Naukowe PWN.

Kwaśnica R. (1995). "Wprowadzenie do myślenia o wspomaganiu nauczycieli w rozwoju,” in H. Kwiatkowska, T. Lewowicki (eds.), Z zagadnień pedeutologii i ksztatcenia nauczycieli, Warszawa: Wydawnictwo Instytutu Technologii Eksploatacji, pp. 9-43.

Kwiatkowski S.M. (2007). "Edukacja dorosłych,” in S.M. Kwiatkowski, A. Bogaj, B. Baraniak (eds.), Pedagogika pracy, Warszawa: Wydawnictwo Akademickie i Profesjonalne, pp. 189-207.

Kwiatkowski T., Walczak D. (2017). Kompetencje interpersonalne w pracy wspótczesnego nauczyciela, Warszawa: Wydawnictwo Akademii Pedagogiki Specjalnej im. Marii Grzegorzewskiej.

Łukasik J.M. (2010). "Udana rozmowa z uczniem jest możliwa," Psychologia w Szkole, no. 4, pp. 60-66.

Madalińska-Michalak J., Góralska R. (2012). Kompetencje emocjonalne nauczyciela, Warszawa: Wolters Kluwer Polska SA.

Marynowicz-Hetka E. (2007), Pedagogika spoteczna, vol. 1, Warszawa: Wydawnictwo Naukowe PWN. 
Męczkowska A. (2003). “Kompetencja," in J.M. Śnieciński (ed.), Encyklopedia pedagogiczna XXI wieku, vol. 2, Warszawa: Wydawnictwo Akademickie "Żak", pp. 693-696.

Pawłowska R. (1986). Poradnictwo pedagogiczne, Warszawa: Wydawnictwa Szkolne i Pedagogiczne.

Rubacha K. (2017). "Metodologiczne parametry pedagogiki resocjalizacyjnej," in M.H. Kowalczyk, M. Fopka-Kowalczyk, K. Rubacha (eds.), Uwarunkowania i wieloptaszczyznowość badań nad resocjalizacją. Podstawy teoretyczne i metodologiczne, Toruń: Wydawnictwo Naukowe Uniwersytetu Mikołaja Kopernika, pp. 111-150.

Sajdak A. (2010). "Kształtowanie kompetencji dydaktycznych pedagogów," in A. Sajdak, D. Skulicz (eds.), Paradygmaty akademickiego ksztatcenia pedagogów, Kraków: Wydawnictwo Uniwersytetu Jagiellońskiego, pp. 129-143.

Sajkowska M. (2001). "Przemoc wobec dzieci - patologia czy normalność," in B. Fatyga, A. Tyszkiewicz (eds.), Normalność i normalka. Próba zastosowania pojecia normalności do badań mtodzieży, Warszawa: Instytut Stosowanych Nauk Społecznych, pp. 193-213.

Siarkiewicz E. (2010). Przestonięte obszary poradnictwa. Realia - iluzje ambiwalencje, Zielona Góra: Oficyna Wydawnicza Uniwersytetu Zielonogórskiego.

Siarkiewicz E., Trębińska-Szumigraj E., Zielińska-Pękał D. (2012). "Rzecz o refleksyjnym praktyku-badaczu, czyli o niekonwencjonalnych sposobach kształcenia doradców," in M. Olejarz (ed.), Dyskursy mtodych andragogórw, vol. 13, Zielona Góra: Oficyna Wydawnicza Uniwersytetu Zielonogórskiego, pp. 105-127.

Szempruch J. (2012). Nauczyciel w warunkach zmiany spotecznej i edukacyjnej, Kraków: Oficyna Wydawnicza "Impuls".

Szempruch J. (2013). Peudeutologia. Studium teoretyczno-pragmatyczne, Kraków: Oficyna Wydawnicza "Impuls".

Szumigraj M. (2009). "O problemie w poradnictwie," in A. Kargulowa (ed.), Poradoznawstwo - kontynuacja dyskursu. Podręcznik akademicki, Warszawa: Wydawnictwo Naukowe PWN, pp. 173-198.

Tischner J. (1982). Myślenie wedlug wartości, Kraków: Znak.

Wiatrowski Z. (2005). Podstawy pedagogiki pracy, Bydgoszcz: Wydawnictwo Akademii Bydgoskiej im. Kazimierza Wielkiego.

Wojtasik B., Kargulowa A. (2003). Doradca-profesja, pasja, powotanie. Materiaty ze Światowego Kongresu Poradnictwa Zawodowego, vol. 3, Warszawa: Stowarzyszenie Doradców Szkolnych i Zawodowych Rzeczypospolitej Polskiej.

Zielińska-Pękał D. (2009). "Poradnictwo a świat mediów czyli o poradnictwie zapośredniczonym," in A. Kargulowa (ed.), Poradoznarwstwo kontynuacja dyskursu. Podręcznik akademicki, Warszawa: Wydawnictwo Naukowe PWN, pp. 285-307. 


\section{ADDRESS FOR CORRESPONDENCE}

Barbara Adamczyk

Jesuit University Ignatianum in Krakow

Institute of Pedagogical Sciences

e-mail: barbara.adamczyk@ignatianum.edu.pl 